\title{
In vitro Antioxidant and Antihaemolytic Potential of Triticum aestivum Grass
}

\section{Abstract}

Triticum aestivum belongs to family Poaceae. Its grass is rich in nutrient. In present study, four different extracts (petroleum ether, ethyl acetate, n-butanol, aqueous) of Triticum aestivum grass were used to test the antioxidant and antihaemolytic activity. In phytochemical screening n-butanol and aqueous extract were found to possess high concentration of flavonoids when content compared with other phytochemicals were present in moderate and low concentration. Different parameters i.e. reducing power, NO radical scavenging activity, DPPH radical scavenging activity, Superoxide dismutase assay were used to test antioxidant power of Triticum aestivum grass. n-butanol and aqueous extracts scavenge the free radicals maximally. Maximum antihaemolytic activity was found in n-butanol extracts. Thus, it is deduced that Triticum aestivum shows maximum antioxidant and antihaemolytic activity in n-butanol and aqueous extract in comparison to other two extracts.

Keywords: Triticum aestivum; Antioxidant; Antihaemolytic; SOD; Phytomedicine

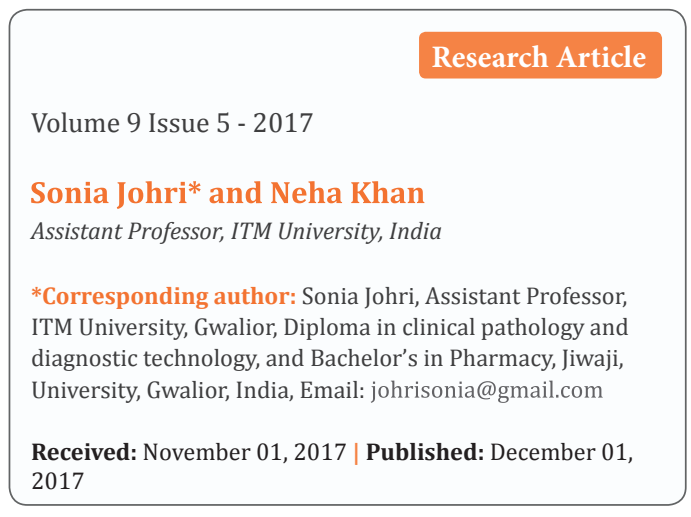

\section{Introduction}

Plants are the good source of phenolic and polyphenolic compound having potent antioxidant activities which can be exploited in preparation of food and pharmaceutical product [1]. Being a rich source of secondary metabolites, medicinal plants are used by native people from ancient times and play a pivotal role as therapeutic and lifesaving drugs [2]. Herbal medicines are adventitious over synthetic medicines as they have varied properties and $70 \%$ of the world population is dependent on such population [3]. Use of phytomedicine is gaining importance as they have the capability to treat many diseases without any side effects and used in preparation of creams, decoctions, syrups and infusions.

T. aestivum (wheat) belongs to Poaceae family is maximum edible cereal rich in vitamins, minerals and proteins as compared to mature cereal plant [4]. It is rich in chlorophyll, minerals (Ca, $\mathrm{K}, \mathrm{Na}, \mathrm{Mg}, \mathrm{S}$ ) and contain 17 amino acids, vitamins and active enzymes [5]. It is usually used as a herbal medicine in many diseases like thalassemia and myrlodysplastic syndrome [6,7]. In addition is also been supposed to strengthen the immune system and increase the life span of cancer patients by preventing the spread of cancer cells [8].

Oxidative balance is defined to be a state when rate of production and removal of free radicals is balanced. Any change in the decrease rate of removal or increase production of free radicals leads to the generation of ROS which finally results in oxidative stress. An antioxidant can scavenge the free radicals due to their redox hydrogen donators and singlet oxygen quencher [9]. Due to insufficient number of antioxidants, free radicals cannot be neutralized and results in oxidative stress are generated. Oxidative stress is lead to several diseases like cardiovascular diseases, cancer and aging [10].

Haemolytic anaemia is a condition in which red blood cells are destroyed and removed from the bloodstream before their normal lifespan is over resulting in reducing number of cells. It may be caused due to various causative agents such as environmental toxicants, malaria, and dengue etc [11]. Many researchers supported the study of mechanism of haemolytic actions of several agents on RBCs and it has been reported that haemolytic injury is related with oxidative stress. Haemolytic agents have been reported to cause membrane lipid per oxidation and denaturation of cytoskeletal protein [12].

Wheatgrass fresh juice is used as a nutritional supplement since decades [13]. The aim of this study was to evaluate the antioxidant and antihaemolytic properties of T. aestivum grass in four different extracts and its use to cure haemolytic anaemia.

\section{Materials and Methods}

\section{Extraction of plant material}

The grass of T. aestivum was cultivated, chopped, dried in shade and powdered with a mechanical grinder.

$50 \mathrm{~g}$ of powder was weighed and extracted with soxhlet apparatus using various solvent according to their polarity i.e. petroleum ether, ethyl acetate, n-butanol and water. After solvent extraction, it was evaporated to obtain a powdered extract for various biochemical analyses.

\section{Qualitative phytochemical screening of $T$. aestivum grass in four extracts}

Preliminary phytochemical screening of the extracts was performed for the presence of alkaloids, flavonoids, steroids, tannins, saponin and phenol using the standard procedures.

a. Alkaloids: To $1 \mathrm{ml}$ of extract, 2-3 drops of Wagner's reagent were added. The appearance of pale or white precipitate indicated the presence of alkaloids [14]. 
b. Steroids: To $2 \mathrm{ml}$ of extract, $2 \mathrm{ml}$ of chloroform and $2 \mathrm{ml}$ of concentration sulphuric acid was added. Tubes were shaken and allowed to stand. Formation of red colour chloroform layer indicates the presence of steroids [15].

c. Tannins: $3 \mathrm{ml}$ of extracts was treated with $1 \%$ lead acetate solution. A red or yellow colour precipitate was formed, indicating the presence of tannins [14].

d. Saponins: To $3 \mathrm{ml}$ of extracts, few drops of sodium bicarbonate was added and shaken vigorously for $3 \mathrm{~min}$. Honey comb froth was formed, showing the presence of saponins [15].

e. Phenolic: To $1 \mathrm{ml}$ of extracts, $2 \mathrm{ml}$ of distilled water and few drops of $10 \%$ ferric chloride solution were added. Formation of blue or green colour indicates the presence of phenols [14].

f. Flavonoids: To2 $\mathrm{ml}$ of each extract was added few drops of $20 \%$ sodium hydroxide, formation of intense yellow colour is observed, and by adding 70\% hydrochloric acid yellow colour disappeared. Disappearance of yellow colour indicates the presence of flavonoids in the extract [16].

\section{Reducing power assay}

$2.5 \mathrm{ml}$ phosphate buffer $(0.2 \mathrm{M}, \mathrm{pH} 6.6)$ and $2.5 \mathrm{ml} 1 \%$ potassium ferrocyanide was mixed in $1 \mathrm{ml}$ of different fraction of plant extract at various concentration $(20,80,120,240 \mu \mathrm{g} /$ $\mathrm{ml}$ ) diluted in distilled water. The test tubes were incubated at $50^{\circ} \mathrm{C}$ in water bath for $10 \mathrm{~min}$. followed by addition of $2.5 \mathrm{ml} 10 \%$ TCA and centrifuge at $3000 \mathrm{rpm}$ for $10 \mathrm{~min}$. $2.5 \mathrm{ml}$ of upper layer was collected, and $2.5 \mathrm{ml}$ distilled water was added followed by $0.5 \mathrm{ml} 0.1 \% \mathrm{feCl}_{3}$ (freshly prepared). Increase in absorbance was measured at $700 \mathrm{~nm}$ against a suitable blank [17].

\section{NO radical scavenging activity}

NO radical scavenging activities of plant extract in different fraction were examined by Royer et al. [18]. To $200 \mu \mathrm{l}$ sodium nitroprusside $(5 \mathrm{Mm}), 800 \mu \mathrm{l}$ extracts $(0.1-1 \mathrm{mg} / \mathrm{ml})$ was added dissolved in PBS (25mM, pH 7.4). The mixture was incubated for $2.5 \mathrm{hr}$ at $37^{\circ} \mathrm{C}$ under normal light and followed incubation in dark for 20 min., $600 \mu \mathrm{l}$ Griess reagent (1\% sulphanilamide, $0.1 \%$ naphthyl ethylene diamine hydrochloride in $2 \%$ phosphoric acid) was added and incubated for $40 \mathrm{~min}$. at room temperature and absorbance was measured at $540 \mathrm{~nm}$ against a suitable blank $(2 \mathrm{ml}$ $\mathrm{H}_{2} \mathrm{O}$ and $0.6 \mathrm{ml}$ Griess reagent). Control (1.6 $\mathrm{ml} \mathrm{H}_{2} \mathrm{O}, 400 \mu \mathrm{l}$ SNP and $600 \mu \mathrm{l}$ Griess reagent) was prepared and percent of inhibition was calculated by using this equation.

Percentage inhibition $=$ OD of control - (OD of extract $/$ OD of control) x 100 ---- (1)

\section{DPPH free radical scavenging activity}

DPPH free radical scavenging activity of plant extracts in different fraction was examined by Blois method [19] with minor modification. To $2 \mathrm{ml}$ of plant extract taken at various Concentrations $(20-100 \mu \mathrm{g} / \mathrm{ml}), 1 \mathrm{ml}$ of DPPH solution $(0.1 \mathrm{Mm}$ in methanols) was added, shaken well and incubated at $37^{\circ} \mathrm{C}$ for $30 \mathrm{~min}$ in dark. Decrease in absorbance was measured at $517 \mathrm{~nm}$ spectrophotometrically against a suitable blank and control tube which contains methanol and DPPH without extract. The percentage of inhibition was calculated by using equation 1 .

\section{Superoxide Dismutase (SOD) Assay}

This assay was done by the method of Kakkar et al. [20]. Fresh wheatgrass $(0.5 \mathrm{~g})$, were ground with $5.0 \mathrm{ml}$ of sodium phosphate buffer $(50 \mathrm{mM}, \mathrm{pH} 6.4)$ centrifuged at $2000 \mathrm{~g}$ for $10 \mathrm{~g}$ and supernatant were collected used for the assay.

Assay mixture contained $1.2 \mathrm{ml}$ of Sodium pyrophosphate buffer $(0.025 \mathrm{M}, \mathrm{pH} 8.3), 0.1 \mathrm{ml}$ of phenazine methosulphate $(186 \mu \mathrm{M}), 0.3 \mathrm{ml}$ of nitro blue tetrazolium $(300 \mu \mathrm{M}), 0.2 \mathrm{ml}$ of plant extract at different concentration $(20-100 \mu \mathrm{g} / \mathrm{ml})$ and distilled water in a total volume of $2.8 \mathrm{ml}$. The reaction was initiated by addition of $0.2 \mathrm{ml} \mathrm{NADH}(780 \mu \mathrm{M})$. The mixture was incubated at $30{ }^{\circ} \mathrm{C}$ for 90 secs. $1 \mathrm{ml}$ glacial acetic acid to stop the reaction. Reaction mixture was shaken with $4 \mathrm{ml} \mathrm{n}$-butanol, and allowed to stand for $10 \mathrm{~min}$. It was centrifuged at $2000 \mathrm{~g}$ for $10 \mathrm{~min}$. and butanol layer was collected. The intensity of chromogen n-butanol layer was measured at $560 \mathrm{~nm}$. The percent of inhibition was calculated by using equation (2).

Percentage inhibition $=(O D$ of control - OD of extract/OD of control x mg of protein) x 100---- (2)

\section{Antihaemolytic activity/ Membrane stabilizing activity}

The following two methods were used for conducting in vitro membrane stabilizing assay:

i. Hypotonic solution-induced haemolysis: This method was done by method of Shinde et al. [21]. $5 \mathrm{ml}$ of whole blood of a healthy person in heparinized tube was collected. The blood was centrifuged at $3000 \mathrm{~g}$ for $10 \mathrm{~min}$. supernatant was removed and RBCs were washed three times with sodium chloride isotonic solution $(154 \mathrm{mM} \mathrm{NaCl})$ in $10 \mathrm{mM}$ Sodium phosphate buffer ( $\mathrm{pH}$ 7.4) through centrifugation using the same volume as supernatant. Finally, RBCs were resuspended in the same volume of isotonic buffer solution. $0.5 \mathrm{ml}$ of RBCs suspension was mixed with $5 \mathrm{ml}$ of hypotonic solution $(50 \mathrm{mM}$ $\mathrm{NaCl}$ in $10 \mathrm{mM}$ sodium phosphate buffer $\mathrm{pH} 7.4$ ) containing $0.5 \mathrm{ml}$ plant extracts $(10 \mathrm{mg} / \mathrm{ml})$. The control sample was prepared by $0.5 \mathrm{ml}$ suspension mixed with hypotonic buffered saline. The mixture was incubated for $10 \mathrm{~min}$. at room temperature, centrifuged at $3000 \mathrm{~g}$ for $10 \mathrm{~min}$. and the optical density of supernatant was measured at $540 \mathrm{~nm}$.

ii. $\mathbf{H}_{2} \mathbf{O}_{2}$ induced haemolysis: This method was done by Ebrahimzadeh et al. [22]. $5 \mathrm{ml}$ whole blood was collected in heparinized tube, centrifuged (10 min. at $1500 \mathrm{~g}$ ) RBCs were separate out from plasma and buffy coat was obtained, after three washes in 10 volumes of $10 \mathrm{mM} / \mathrm{L}$ PBS, washed RBCs were diluted in PBS to obtained $4 \%$ suspension. To $2 \mathrm{ml}$ RBCs suspension, $1 \mathrm{ml}$ of plant extracts $(10 \mathrm{mg} / \mathrm{ml})$ was added and incubated for $5 \mathrm{~min}$. at room temperature, $0.5 \mathrm{ml}$ $\mathrm{H}_{2} \mathrm{O}_{2}$ was added shaken well and incubated at $37^{\circ} \mathrm{C}$ for 30 min. Supernatant was collected and absorbance was read at $540 \mathrm{~nm}$. Percentage inhibition of was calculated by using equation 1. 
iii. Statistical analysis: All data were expressed as mean+standard deviation from three repeats $(n=3)$ experiments. The free radical scavenging activity was calculated by using Graph Pad Prism 7 ink. Software.

\section{Results and Discussion}

The qualitative test for alkaloids, flavonoids, tannins, phenols, saponins, and steroids from four different extract. T. aestivum grass was investigated. The Table 1 explains the phytochemical

Table 1: Phytochemical screening of T. aestivumin four extracts extract.

\begin{tabular}{|c|c|c|c|c|c|c|}
\hline Extract & Alkaloids & Flavonoids & Tannins & Phenols & Saponins & Steroids \\
\hline Petroleum ether & + & ++ & + & + & + & + \\
\hline Ethyl acetate & + & ++ & + & + & + & + \\
\hline n-butanol & ++ & +++ & + & + & + & + \\
\hline Aqueous & ++ & +++ & + & + & + & + \\
\hline
\end{tabular}

+: low concentration; ++: Moderate concentration; +++: high concentration

Figure 1 shows the reducing power of four extracts of wheatgrass at $700 \mathrm{~nm}$. At physiological pH (7.4), ferrous ions $\left(\mathrm{Fe}^{2+}\right)$, in the presence of oxygen and phosphate ions $\left(\mathrm{PO}_{4}^{2-}\right)$, exist only transiently before being auto-oxidized to ferric ion $\left(\mathrm{Fe}^{3+}\right)$. During this process, an electron is transferred from iron to oxygen to form a superoxide radical anion and hydroperoxyl radical $\left(\mathrm{HO}_{2} \cdot{ }^{\cdot}\right)$ by Fenton reaction. Highest reducing abilities 1.008 were observed in aqueous extract of wheatgrass followed by n-butanol extracts $(0.760)$ at $240 \mu \mathrm{g} / \mathrm{ml}$ concentration. The high reducing power which was concentration-dependent of the aqueous extract of wheat grass may be attributed to the fact that the extract possessed the ability to be effective, under physiological conditions, in reducing the transition state of iron and consequently, the rate at which superoxide and hydroperoxyl radicals are generated from the metal. A strong relationship between the total phenolic content and reducing activity in fruits and vegetables has been reported [26]. Therefore, the reducing power of the extract may be attributed to its phenolic content.
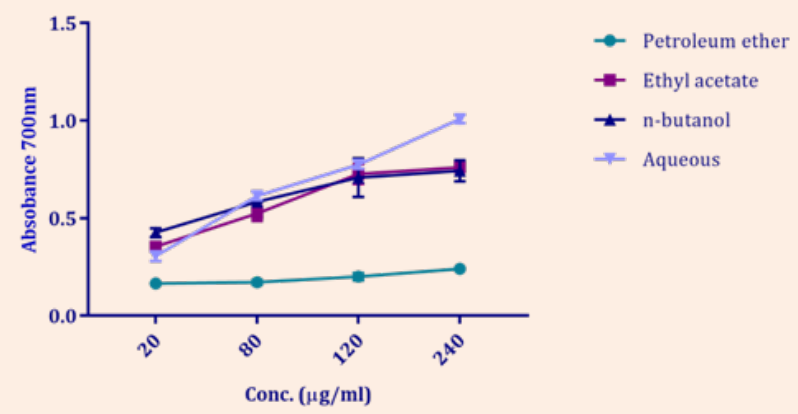

Figure1: Reducing power of T. aestivum grass in four extracts.

Figure 2 represents the NO scavenging activity of wheatgrass in four extracts. The maximum scavenging activity was found in aqueous extract 60.7 at $1 \mathrm{mg} / \mathrm{ml}$ as compared to others extracts. screening indicates the presence of alkaloids, flavonoids, tannins, phenols, saponins, steroids. Flavonoids were present in very high concentration which indicates rich antioxidant property. Studies have shown that many of the phytocompounds possess anti-inflammatory, anti-diabetic and antimicrobial activities [23]. In recent years, secondary plant metabolites (phytochemicals), previously with unknown pharmacological activities, have been extensively investigated as a source of medicinal agents [24]. Wheatgrass proved to be an effective radical scavenger in all antioxidant assay [25].

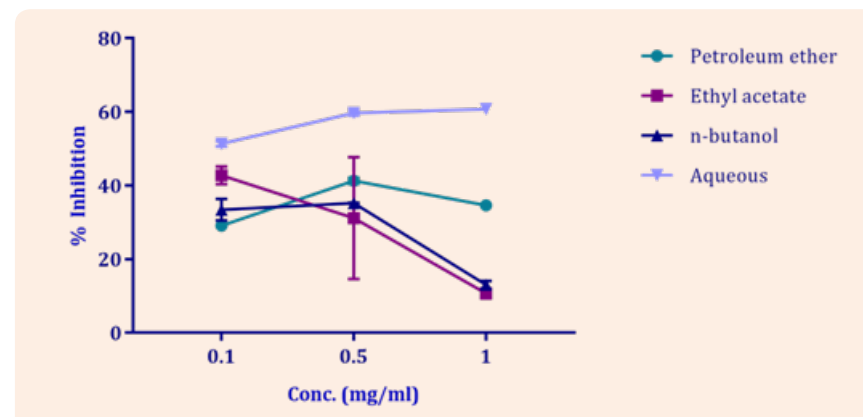

Figure 2: NO radical scavenging activity of T. aestivum grass in four extracts.

Free radicals arbitrarily react with lipids, proteins and nucleic acids causing oxidative stress and damage in these macromolecules leading to age-related and chronic diseases $[27,28]$. Flavonoids or bioflavonoids are ubiquitous group of polyphenolic substances which can be correlated to the maintenance of antioxidant status [29]. Numerous studies have shown that flavonoids possess potent antioxidant activities capable of scavenging hydroxyl radicals, superoxide anions, and lipid peroxy radicals [30]. The antioxidant potential of wheatgrass extracts was investigated in the search for new bioactive compounds from natural resources. The obtained results for DPPH agree with the phenolic contents which was determined for each sample. Plant polyphenols act as reducing agents and antioxidants by the hydrogen-donating property of their hydroxyl groups [31]. The effect of antioxidants on DPPH is thought to be due to their hydrogen donating ability [32].

Hence, we can conclude that polyphenols are responsible for the observed antioxidant activity in this study. Figure 3 shows the DPPH radical scavenging activity. The highest scavenging activity was observed in n-butanol extract ( 60.3 at $100 \mu \mathrm{g} / \mathrm{ml}$ ) followed by ethyl acetate extract $(52.7$ at $80 \mu \mathrm{g} / \mathrm{ml})$. Though the DPPH radical 
scavenging abilities of the extracts were less than those of ascorbic acid the study showed that the extracts have the proton-donating ability and could serve as free radical inhibitors or scavengers, acting possibly as primary antioxidants.

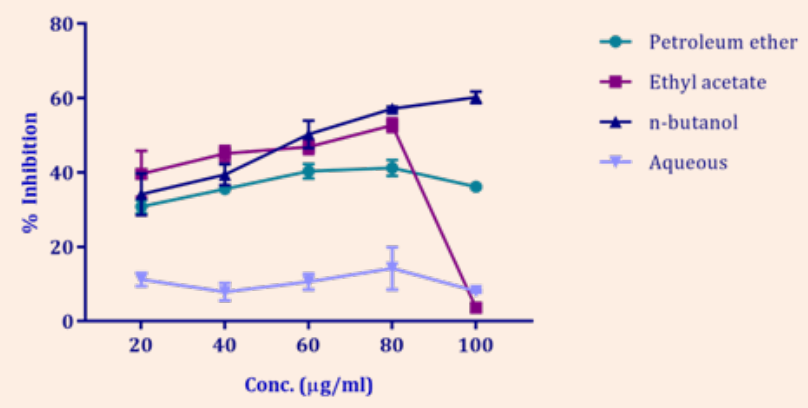

Figure 3: DPPH free radical scavenging activityof T. aestivum grass in four extracts.

Superoxide dismutase activity from the fresh sample was examined at various concentration of extract. Table 2 represent the SOD activity of wheat grass. Percentage of inhibition was found to be maximum at $60-80 \mu \mathrm{g} / \mathrm{ml}$. SOD is thought to play a very important role in protecting living cells against toxic damage to free radicals. The enzyme catalyses the dismutation of two superoxide radicals $\left(\mathrm{O}_{2}^{-}\right)$into $\mathrm{O}_{2}$ and $\mathrm{H}_{2} \mathrm{O}_{2}$ [33]. Table 2 shows the activity of pure superoxide dismutase assay at different concentration. Result indicates maximum inhibition at 60$80 \mu \mathrm{g} / \mathrm{ml}$ concentration. This concentration is effective to reduce $\mathrm{O}_{2}^{-}$radical. The SOD catalyses the dismutation of superoxide to hydrogen peroxide and oxygen, thereby reducing the likelihood of superoxide anion reacting with nitric oxide to form reactive peroxynitrite [34].

Table 2: Superoxide dismutase activity of T. aestivum grass.

\begin{tabular}{|c|c|c|}
\hline S.No. & Concentration $(\boldsymbol{\mu g} / \mathbf{m l})$ & \% Inhibition \\
\hline 1 & 20 & $21.9+0.6$ \\
\hline 2 & 40 & $37.1+3.7$ \\
\hline 3 & 60 & $40.9+0.63$ \\
\hline 4 & 80 & $39.3+2.2$ \\
\hline 5 & 100 & $36.5+2.5$ \\
\hline
\end{tabular}

Data represent as mean + SD $(n=3)$.

Table 3 explains the antihaemolytic activity. In case of hypotonic solution induced haemolysis, the maximum level of membrane stabilizing activity was observed by n-butanol fraction of wheatgrass which was $75 \%$ by $\mathrm{H}_{2} \mathrm{O}_{2}$ induced haemolysis and $82 \%$ by hypotonic solution induced haemolysis. The minimum antihaemolytic activity was exhibited by petroleum ether extract of wheatgrass. The ranges of antihaemolytic of all extracts were between $65-82 \%$. The extract was quite effective in membrane stabilization studies and stabilization of erythrocyte which could be correlated to the stabilization of the lysosomal membrane [35] Therefore, the high membrane stabilizing activity of the extract may be due to the presence of flavonoids or saponins since tannins were minimally present in the extract. The findings on the aqueous extract of wheat grass leaves in this study are like those reported by Sadique et al. [36] \& Olugbenga et al. [37].
Table 3: Induced haemolytic activity of T. aestivum.

\begin{tabular}{|c|c|c|}
\hline Fractions & $\begin{array}{c}\mathrm{H}_{2} \mathrm{O}_{2} \text { Induced } \\
\text { Antihaemolysis } \\
\text { Activity }(10 \mathrm{mg} / \mathrm{ml})\end{array}$ & $\begin{array}{c}\text { Hypotonic } \\
\text { Solution Induced } \\
\text { Antihaemolysis } \\
(10 \mathrm{mg} / \mathrm{ml})\end{array}$ \\
\hline Control & $100 \%$ & $100 \%$ \\
\hline Petroleum ether & $65 \%$ & $62 \%$ \\
\hline Ethyl acetate & $68 \%$ & $68 \%$ \\
\hline n-butanol & $82 \%$ & $75 \%$ \\
\hline
\end{tabular}

\section{Conclusion}

In this study, T. aestivum grass shows maximum antioxidant and antihaemolytic activities in aqueous and n-butanol extracts in comparison to petroleum ether and ethyl acetate extracts. It may due to the presence of high flavonoid content in these two extracts. These extracts have potent antioxidant and antihaemolytic activities. Further study needs to show the antioxidant and antihaemolytic activities more effectively. Further investigation both in vivo and in vitro needs to be explore for antianemic and antioxidant efficacy of the T. aestivum grass extracts.

\section{Acknowledgement}

Authors are highly acknowledged to MPCST (M.P. Council of science and Technology) Bhopal, Gwalior M.P., for providing research grants to support this research work. Authors acknowledge ITM university for providing lab and instrument facility.

\section{Conflict of Interest}

Authors declare no conflict of interest.

\section{References}

1. Li H, Hao Z, Wang X, Huang L, Li J (2009) Antioxidant activities of extracts and fractions from Lysimachiafoenum-graecumHance. BioresTechnol (100): 970-974.

2. Bewaji CO, Olorunsogoand EA, Bababumi (1985) Sickle cell membrane-bound $(\mathrm{Ca} 2+$ and $\mathrm{Mg} 2+)$-ATPase: Activation by 3,4-dihydro-2, 2-dimethyl-2H-1-1-benzopyran-6- butyric acid. A novel antisickling agent. Cell Calcium (6): 237- 244.

3. Olagunjua JA, Adeneyeb BS, FagbohunkacNA, Bisugac AO, Ketikuc AS, et al. (2009) Nephroprotective activities of the aqueous seed extract of Carica papaya Linn. in carbon tetrachloride induced renal injured Wistar rats: a dose-and time-dependent study. Bio Med 1(1): 11-19.

4. Tirgarl PR, Thumber BL, Desai TR (2011) Isolation characterization and Biologocical evaluation of iron chelator from Triticumaestivum (Wheatgrass). Int J Pharm biosci 2(4): 288-296.

5. Lee SH, Jew SS,Chang PS, Hong IJ, Hwang ES, et al. (2003) Free radical scavenging effect and antioxidant activities of barley leaves. Food Sci Biotech 12(3): 268-273.

6. Marawaha RK, Bansal D, Kaur S, Trehan A (2004) Wheatgrass juice reduces transfusion requirement in patients with thalassemia major: a pilot study. Indian Pediatr 1(7): 716-720.

7. Mukhopdhyay S, Basak J, Kar M, Mandal S, Mukhopdhyay A (2009) 
The role of iron chelation activity of wheat grass juice in patients with myelodysplatic syndrome. J Clin Oncol 27(155): 15.

8. Moller JKS, Madsen HL, Aaltonen T, Skibsted LH (1999) Dittany (Origanumdictamnus) as a source of water-extractable antioxidant. Food chem 64(2): 215-219.

9. Naskar S, Islam A, Mazumdar UK, Saha P, Haldar PK, et al. (2010) In vitro and In vivo antioxidant potential of hydromethanolic extract of Phoenix dactyliferafruits. J Sci Res 2(1): 144-157

10. Borneo R, Leon AE, Aguirre A, Ribotta P, canter JJ (2008) Antioxidant capacity of medicinal plants from the Province of Cordoba (Argentina) and their in vitro testing in a model food system. Food Chem. 112(3): 664-670.

11. Ross, Wilson (2006) Anatomy and physiology in health and illness ( $7^{\text {th }}$ edition), Elsvie, Churchill Livingstone, UK, p. 70-71.

12. Jollow DJ, McMillan DC (2001) Oxidative stress, glucose-6 phosphate dehydrogenase and the red cell. Adv Exp Med Biol 500: 595-605.

13. Shakya G, Madhu Sudhana RK, Sankar P, Rukkumani R (2012) Antihyperglycaemic and antihyperlipidaemic effect ofwheatgrass on streptozotocin induced type 2 diabetic rat (2012). J Pharm Res 5(5): 2580-2583.

14. Harborne JB (1973) Phytochemical methods. ( $2^{\text {nd }}$ edn), Chapman and Hall Ltd, London, pp. 149-188.

15. Kumar S, Sharma UK, Sharma AK, Pandey AK (2012) Protective efficancy of Salanumxanthocarpum root extract against free radical damage. Phytochemical analysis and antioxidant effect. Cell Mol Bio 58 (1): 174-181.

16. Prabhavathi RM, Prasad MP, Jayaramu M (2016) Studies on qualitative and quantitative phytochemical analysis of cissusquadragularis. Adv appl sci res 7(4): 11-17.

17. Benzie IF, Strain JJ (1996) The ferric reducing ability of plasma (FRAP) as a measure of "antioxidant power": the FRAP assay. Anal biochem 239(1): 70-76.

18. Royer M, Diouf PN, Stevanovic T (2011) Polyphenol contents and radical scavenging capacities of red maple (Acer rubrum L.) extracts. Food ChemToxicol 49(9): 2180-2188.

19. Esmaeili MA, Sonboli A (2010) Antioxidant, free radical scavenging activities of Salvia brachyantha and its protective effect against oxidative cardiac cell injury. Food Chem Toxico 48(3): 8468-8453.

20. Kakkar P, Das B, Viswanathan PN (1984) A modified spectrophotometric assay of superoxide dismutase. Ind J Biochem Biophys 21(2): 130-132.

21. Shinde UA, Phadke AS, Nair AM, Mungantiwar AA, Dikshit VJ, et.al (1999) Membrane stabilizing activity-a possible mechanism of action for the anti-inflammatory activity of Cedrusdeodarawood oil. Fitoterapia 70(3): 251-257.

22. EbrahimzadehMA,NabaviSF,EslamiB,NabaviSM(2009)Antioxidant and antihaemolytic potentials of Physosperumcornubiense (L.) DC. Pharmacologyonline 3: 394-403.
23. Joan IA, Campbell-Tofte, Per Molgaard, KajWinther (2012) Harnessing the Potential Clinical Use of Medicinal Plants as AntiDiabetic Agents. Bot: Targ Therap 2: 7-19.

24. Alluri V, Tayi K, Rao VN, Dodda S, Vanisree M, et al. (2005) Assessment of Bioactivity of Indian Medicinal Plants Using Brine Shrimp (Artemiasalina) Lethality Assay. Int J Appl Sci Engineer 3: $125-130$

25. Sankar P, Preedia B, Rukkumani R (1995) Phytochemical and analysis of antioxidant properties of aqueous extracts of wheatgrass. Asian Pac J Trop Med 7(1): 398-404

26. Yildrim A, Mavi A, Kara AA (2001) Determination of antioxidant and antimicrobial activities of Rumexcrispus L. extracts. J Agric Food Chem 49(8): 4083-4090.

27. Mishra A, Sharma AK, Kumar S, Saxena AK, Pandey AK (2013) Bauhinia variegata Leaf Extracts Exhibit Considerable Antibacterial, Antioxidant, and Anticancer Activities. Bio Med Res In 2013 915436.

28. Fang Y, Yang S, Wu G (2002) Free radicals, antioxidants, and nutrition. Nutr 18(10): 872-879.

29. Alan L, Miller ND (1996) Antioxidant flavonoids: structure, function and clinical usage. Altern Med Rev 1(2): 103-111.

30. Amic D, Amic DD, Beslo D, Rastija V, Lucic V, et al. (2007) SAR and QSAR of the antioxidant activity of flavonoids. Curr Med Chem 14(7): 827-845.

31. Aberoumand A, Deokule SS (2008) Comparison of phenolic compounds of some edible plants of Iran and India. Paki J Nutri 7: 582-585.

32. Adeolu AA, Florence OJ, Anthony JA, Patrick JM (2009) Antioxidant Properties of the Methanol Extracts of the Leaves and Stems of Celtis. Afric Rec Nat Prod 3(1): 23-31

33. McCord JM, FridovichI (1964) Superoxide dismutase. An enzymic function for erythrocuprein (hemocuprein). J BiolChem 244(22): 6049-6055.

34. Maritim AC, Sanders RA, Watkin JB (2003) Diabetes, oxidative stress, and antioxidants: a review. J Biochem Molec Toxicol 17(1): 24-38.

35. Oyedapo 00, Akinpelu BA, Orefuwa SO (2004) Anti-inflammatory effect of Theobroma cacao, root extract. Trop Med Plants 5: 161166

36. Sadique J, Al-Raqobah WA, Bugharith ME, El-Gindy AR (1989) The bioactivity of certain medicinal plants on the stabilization of RBC membrane system. Fitoterapia 60: 525-532.

37. Olugbenga M, Fafunso MA, Makinde JM (2005) Membrane stabilizing activity: A possible mechanism of action of the anti-inflammatory property of Gongronemalatifolium leaves. Int J Biomed Health Sci 1: $1-4$. 